\title{
E-Learning Evolution and Development From the Perspectives of Technology, Education, and Economy
}

\author{
Vy Dang Bich Huynh ${ }^{1}$, Phong Thanh Nguyen ${ }^{2}$, Quyen Le Hoang Thuy To Nguyen ${ }^{3} \&$ Ngoc Bich Vu ${ }^{4}$ \\ ${ }^{1}$ Department of Learning Material, Ho Chi Minh City Open University, Ho Chi Minh City, Vietnam \\ ${ }^{2}$ Department of Project Management, Ho Chi Minh City Open University, Ho Chi Minh City, Vietnam \\ ${ }^{3}$ Office of Cooperation and Research Management, Ho Chi Minh City Open University, Ho Chi Minh City, Vietnam \\ ${ }^{4}$ School of Advanced Study, Ho Chi Minh City Open University, Vietnam \\ Correspondence: Phong Thanh Nguyen, Department of Project Management, Ho Chi Minh City Open University, \\ Vietnam. E-mail: phong.nt@ou.edu.vn
}

Received: December 26, 2019

Accepted: February 14, 2020

Online Published: March 5, 2020

doi:10.5430/rwe.v11n1p11

URL: https://doi.org/10.5430/rwe.v11n1p11

\begin{abstract}
E-learning has been and is an indispensable tool in the knowledge economy. It is attracting the special attention from many universities and educational institutions toward the goal of "learner-centric" because it is highly interactive, based on multimedia, enables learners to give exchange information more easily, and provides learning content that is appropriate to the capabilities and interests of each person. For more than forty years, e-learning has undergone a striking development that has paralleled technological breakthroughs. It, however, comes into the practice of education only upon integration into educational advances and based on the foundation of economic from three pillars: technology, education and economy, thereby highlighting the interactions among these factors and recommending orientations and synchronous solutions in this paper.
\end{abstract}

Keywords: economy, education, techonology, e-learning evolution

\section{Introduction}

The first effort to learn and train empowered by information technology occurred in the late $20^{\text {th }}$ century . In the early years of the $21^{\text {st }}$ century, e-learning development soared in association with advancements in technology and education, based on strong economic and institutional foundations, thereby creating a broad and multidimensional concept (Q. L. H. T. T. Nguyen, Nguyen, \& Huynh, 2019; Rodrigues, Almeida, Figueiredo, \& Lopes, 2019). This paper analyzes how e-learning has developed in relation to technology, education and the economy. This analysis lays the foundation for research into the drivers of e-learning evolution as well as offering new trends in this training and teaching approach.

For purpose of this study, e-learning is understood as an continual innovative teaching and learning method that is empowered by the application of information technology and communication to provide access to resources, services, and management without spatial and temporal limitations, to promote interactions and collaboration in learning, to put learners at the canter of the teaching, and to advocate learner personalization (Alfita, Kadiyono, Nguyen, Firdaus, \& Wekke, 2019; Noesgaard \& Ørngreen, 2015). As such, e-learning is composed of three main pillars: education, technology, and economy. Specifically, technology as a driver of e-learning's continual evolution must be coupled with innovations in teaching and learning methods in order to improve the convenience of delivery and communication to this learner-cantered system. Investigation of an e-learning system should account for all components of the system.

In particular, education aspect is fundamental and refers to learners' and teachers' capacity (Qodim, Herningsih, Nguyen, Nguyen, \& Toding, 2019). Learners must build up digital competence and be able to search, evaluate, and use information in a digitized environment. Teachers who create or guide courses must be able to design and facilitate the learning process on the basis of the application of information and communication technology, so as to build up an interactive and collaborative learning environment, which conveniently provides a learner-cantered, personalized learning process access to resources, services, and system management (Starkey, 2019). The result is to provide a learner-cantered and personalized learning process. Also, educational contents and infrastructure is a key component of the system. Good content requires a theoretical and procedural background for teaching design. Digital content will be built on this groundwork to provide resources, services, and manage the established e-learning learning 
environment. And the technological infrastructure is a condition for e-learning systems to operate. Technological infrastructure must be synchronized at all three stages of operation (including creation, delivery, and receipt) as well as among equipment, connections and software. In addition, for sustainable development, economic aspect or cost benefit analysis is indispensable (Bahrami et al., 2019; Luong, Tran, \& Nguyen, 2018; H. M. Nguyen, Bui, \& Vo, 2019; H. M. Nguyen, Bui, Vo, \& McAleer, 2019; Vo, Van Nguyen, Nguyen, Vo, \& Nguyen, 2019). Therefore, this paper presents e-learning evolution history and development based on three pillars: technology, education and economy (see Figure $1)$.

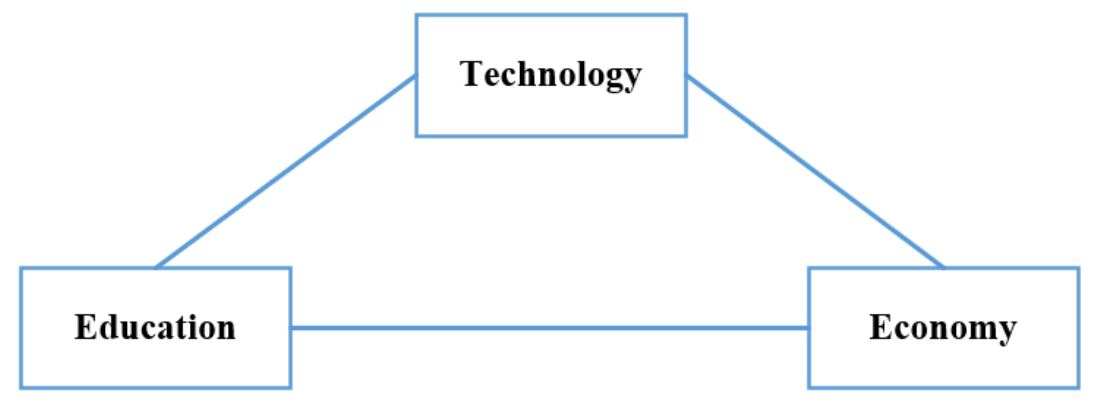

Figure 1. E-learning development from the perspectives of technology, education, and the economy

\section{E-learning Development From the Perspectives of Technology, Education, and the Economy}

\subsection{Technology}

Before network technology gained wide currency in the 1990s, the application of information technology to education existed in teaching and learning support tools such as exam software, multimedia learning material, creating tools (video, eBooks, etc.), and new methods for delivery of learning materials (CD-ROMs, voice, and television, etc.). At first, learners used personal computers only for accessing learning materials that were sent via email or information storage tools like CD-ROM. The teaching and learning tools then were connected to an intranet, which is a local network and has a limited scope (Ayshwarya, Yansyah, et al., 2019; Harasim, 2000; Maseleno et al., 2019; Nguyen Thanh; Phong, Phuc, \& Quyen, 2017). Since the internet was born and developed in the late 20th and early 21 st century, information technology applications that became the foundation of e-learning today along with the development of network technology (Kahiigi Kigozi, Ekenberg, Hansson, Tusubira, \& Danielson, 2008).

(i) Network technology: The embryo of network technology was client-server networks that required user access via a centralized server. Developed internet/intranet/extranet technology-enabled learning in a virtualized environment. The next generation was wireless broadband access technologies, which have supported learning on mobile devices, leading to the formation of mobile learning, e-learning technology, and content development.

(ii) E-learning technology: CD-ROMs containing learning contents brought about the birth of new technologies such as Learning Management Systems (LMS), Learning Content Management Systems (LCMS), virtual communities, and resource-sharing media like YouTube, educational games, development tools, and learner personalization tools. Step-by-step these technologies broadened the ability to interact, collaborate, and manage the learning process (Persico, Manca, \& Pozzi, 2014).

(iii) Content development: Network and e-learning technologies have driven the vigorous and abundant prosperity of e-learning content. The form of learning content has evolved from a primitive textbook to multimedia materials, educational games, and learner-personalized content. The concept of learning objects has gained its shape and plays an important role in e-learning content. It refers to the formation of digital resources that are used repeatedly for different learning environments.

In recent years, the outbreak of social networks has triggered the formation and demand for social network-based online learning (Bari, Djouab, \& Hoa, 2018; Quyen, Nguyen, \& Huynh, 2017; Van Nguyen, Nguyen, Thuy, Nguyen, $\&$ Huynh, 2016). Moreover, thriving data science together with the growth of big data and artificial intelligence have also stimulated the e-learning environment. New trends in e-learning are just over the horizon, such as gamification of learning, microlearning, virtual reality learning, and modelling patterns for teaching. Further, a personalized learning environment will emerge from future developments in big data and artificial intelligence. These technological applications also support the development of adaptive learning, whereby the contents, speed, and 
methods of learning will be adapted to an individual's learning ability (Group, 2017).

When it is not able to be implemented via internet learning activities or combined with different forms of learning to maximize the learner's capacity, blended learning can be used (Kahiigi Kigozi et al., 2008). Recently, this mode of learning has been thriving and, compared to online or traditional learning, received wide acceptance among both learners and teachers (Castaño Muñoz, Redecker, Vuorikari, \& Punie, 2013).

\subsection{Education}

Each step forward in the application of e-learning technology has tended to be linked to a change in pedagogy. Kidd (2010) dissected the pedagogical development stages of e-learning along with the technological evolution. In particular:

(i) In the early stages, e-learning involved the use of supporting applications, teaching, and learning focused on computer models using computers. In general, it involved software-based exercises and practice. At this stage, behaviorism still held a prime role, and teachers substantially functioned as knowledge builders and deliverers. Learners were just passive receivers of knowledge and interactions were very rare.

(ii) When multimedia communication applications first were developed in the 1980s and interactions between learners and computers were activated, constructivists began to hold sway over the process by designing and using educational software even though the learning practice was quite passive.

(iii) The 1990s witnessed an upsurge of the internet with web-based online courses and the widening influence of constructivist theory, which emphasized active learning by group discussions via television, voice, and online forums. The role of teachers shifted from providing passive teaching to administration, discussion, and instruction. However, as with the development of technology, learners' interaction still was quite limited at this stage.

(iv) During the beginning of the $21^{\text {st }}$ century, social network development led to greater and more flexible interactions and broad connections between learners and communities. The learning process under the influence of connectivism began has become a process of exploration, connection, invention, and evaluation with teachers acting as companions and commentators. Therein, connectivism is a theory of learning in a digital age that emphasizes the role of social and cultural context in how and where learning occurs. Learning does not simply happen within an individual, but within and across the networks.

Following the vogue of open education and sharing learning resources, several training institutions and universities have uploaded their courses and learning resources online for everyone to use free of charge. This triggered the birth of open educational resource banks. Some for-profit or non-profit organizations built platforms to gather and deliver free online courses via the Internet, forming the concept of massive open online courses (MOOC). MOOC became a world phenomenon in 2013 (Bari et al., 2018).

\subsection{Economy}

From a niche market valued at around 7 billion USD in 2002, e-learning for the last nearly twenty years has grown into a global market worth hundreds of billions of dollars (Ha, 2013; Ha \& Lam, 2017; Ha \& Nguyen, 2014; JILL, 2018). The global e-learning market in 2015 was estimated at over 165 billion USD and expects to maintain an average annual growth rate of 5\% between 2018 and 2023. Such growth stems from not only technological evolution, educational innovations, but also economic dynamics (Dhahad, Hussen, Nguyen, Ghaebi, \& Ashraf, 2020; Diem \& Ha, 2013; M. H. Nguyen \& B. T. Khoa, 2019b; To, Ha, Nguyen, \& Vo, 2019; Wahyudi et al., 2019). Kasraie and Kasraie (2010) argued that the e-learning economy is composed of three sectors: services, educational contents and infrastructure, and e-learning pursues a transition to services. Accordingly, the construction of buildings or procurement of equipment and textbooks are transformed into services that provide e-learning courses or training programs. In this sense, e-learning is widely used in all forms of education at different levels:

(i) The integration of information technology into general education dates back to the end of the $20^{\text {th }}$ century when it was realized through projects such as APPI (1985-1987), which connected 70 high schools in France, England, Canada and Italy. Nowadays K-12 e-learning is thriving in many parts of the world thanks to generous support from various governments. Government investment came from a desire around the world to enhance national competitiveness in the digital age by nurturing human resources beyond general education levels (Harasim, 2000).

(ii) In regard to formal higher education, universities have spearheaded the research and application of e-learning technology and contents. E-learning is considered a solution to problem of how to improve the training quality through the application of new teaching methods, reinforcement of learners' capacity in the digital age, the scale-up of access to education, the flexible enhancement of training activities, reduction of training costs, and its contribution 
to the universities' reputation and competitiveness. Many countries, especially in the European Union, set out policies on promoting e-learning in higher education in order to enhance economic competitiveness and maintain sustainable development on the basis of its being able to increase jobs and social cohesion (MacKeogh \& Fox, 2009; Phuc, Phong, Vy, \& Quyen, 2017). Kentnor (2015) argued that online learning at US universities was no longer just a trend but has become part of the mainstream. Sixty-nine percent of university leaders considered online learning a critical element in their development strategy. The degree of online training integration into the tertiary curricula is varied, as follows:

- Some online courses are open for student selection.

- Some online programs confer degrees as regular programs do. Many universities have their curriculum crossing the border between online and offline learning.

(iii) For informal higher education, universities providing distance learning programs are keenly aware of the future prospects of e-learning compared to traditional forms of distance education such as correspondence learning or face-to-face learning. Further, e-learning has brought a variety of benefits and values to learners. Equally important, it can be used on a mass scale, which offset the costs of the investment in course design. The first fully online programs, the University of Phoenix (United States) and Open University (UK), were established in the late 1980s (Harasim, 2000). As a part of this education trend, cyber/virtual universities that provide fully online tertiary education also have been founded. For example, South Korea has a system of 18 cyber universities serving nearly 30,000 students (Hwang, Yang, \& Kim, 2010).

(iv) Another path for higher education is forming economic association models to maximize the economies of scale in e-learning. This approach requires an alliance of traditional universities that share resources (software, courses). Open University Australia (OUA), Malaysia Open University offer models. OUA, for example, is a consortium-owned by seven Australian public universities (Curtin, Griffith, Macquarie, Monash, RMIT, Swinburn, South Australia) offering 230 undergraduate and graduate degree programs of these universities in Australia and some other countries. The degrees from OAU cannot be distinguished from those of formal programs.

(v) Adopting this model for use in enterprises has been underway since the 1980s for the purpose of leadership training. As e-learning has come to life, it has gained wide currency as a medium for companies to train newcomers and senior management (Ha \& An, 2015; Ha \& Luan, 2018; Kustandi et al., 2020; P. Nguyen \& Nguyen, 2020; Ramakrishnan, Shabbir, Kassim, Nguyen, \& Mavaluru, 2020). Enterprise e-learning is a well-developed market since companies of all sizes find it is a highly effective training model that can help enterprises ensure the competency of their manpower with a low training cost due to the economies of scale. Since learners do not have to have undivided attention, often they can productively learn and work at the same time (Ha, 2016, 2017; Kasraie \& Kasraie, 2010; H. M. Nguyen \& B. T. Khoa, 2019a, 2019b; H. M. Nguyen, Nguyen, Ngo, \& Nguyen, 2019; Wahyudi et al., 2019).

Sharing models have recently emerged in association with MOOC development. Online courses, as part of universities' digital resources, are shared with communities, so that a university can contribute to their community and to society at large while promoting their reputation. Some remarkable models are:

- Coursera is an enterprise that operates on a platform to provide free courses that are conducted by universities. So far, Coursera has provided more than 2,700 courses and has had more than 150 university and institutional partners and up to 35 million subscribers. Its revenue is mainly generated from courses or short-term training programs that confer certificates.

- Khan Academy is a non-profit organization funded by communities or organizations that develop their own MOOCs to serve the communities.

\section{Analysis of E-learning Evolution History}

Delving into the development history of e-learning allows insight into the cohesion and mutually supportive relations among technology, education, and economy. The technology was a driver of e-learning and still generates that break the existing limits of learning, casting an endless horizon of e-learning development (Moore, Dickson-Deane, \& Galyen, 2011). Education, especially the improvement of the teaching and learning process with increased autonomy of learners, together with a personalized learning process, has made learners the canter of the training process. By mobilizing correct social resources through various models, the economy creates a dynamic for the advancement of technology and education (Ha \& Tam, 2015; H. M. Nguyen, 2018; M. Nguyen, 2011; M. H. Nguyen \& B. T. Khoa, 2019a; Thanh \& Ha, 2013; Vo, Nguyen, \& McAleer, 2019). 
Given the above correlations, the e-learning development process can be split into the following phases:

\subsection{Premise Establishment}

Premise establishment phase dates back to the dawn of computer programs and proceeds in tandem with the wide currency of personal computers until the advent of email. During this phase, connections among computers began to be developed, and newly-established multimedia-enabled the combination of texts, audios, images, animation, videos, and other interactive contents. Technological advancements at this time allowed the application of information technology in education in the form of computer-aided teaching and learning. Educators made their first move from behaviorism to constructivism by using educational software to stimulate a more proactive engagement with learners. However, at this stage, the learning process remained passive due to the fragmentation of applications, technological limitations, and the narrow connections between and among learners.

The majority of investment at this time case from state-owned projects and a few universities, which undertook long-term research and not ad-hoc benefits. Nonetheless, several business models showed up in the form of courses, distance learning programs, and training courses for enterprises that seek to apply new technologies. Software enterprises also took part in producing multimedia learning materials and developing educational software. The market size, however, was small and integral to the general education market.

\subsection{Formation and Development}

Formation and development phase is associated with the advancement of network and internet technology and the introduction of web-based learning-management software (Lwoga, 2014; Nguyen Thanh Phong \& Quyen, 2017; Riyanti et al., 2019; Sutjiatmo et al., 2019). These software programs were able to combine discrete applications from the earlier phase to better organize online courses with better connections among learners and with the training process. This software incorporated digital content creation tools that enabled the formation of more interactive online courses.

In tandem with technological movements, constructivism gained a wider acceptance in education circles. The role of teachers in this period inclined toward administration, discussion, and instruction. Learners became more engaged in self-building their own knowledge foundation and showed more initiative in learning. During this phase, a cohesion between technology and education was cemented, which ledge to a new way of learning. Robust investment in e-learning occurred at universities and among software and digital content developers. This triggered the formation of a soaring e-learning market.

\subsection{The Contemporary Context}

This phase features the advent and evolution of artificial intelligence, data science, big data, and virtual reality, etc., along with booming social networks (Huynh, Nguyen, Nguyen, \& Nguyen, 2018; Muruganantham et al., 2019). The boom in broadband network technology and mobile devices has brought tremendous advantages to internet-based learning (Asih et al., 2019; Ayshwarya, Nguyen, et al., 2019; Ayshwarya, Yansyah, et al., 2019). Cloud computing has helped educational institutions save considerable funds that would have been spent on equipment and learning management systems (Supriyono et al., 2019).

Educators have keenly embarked on technological advancements to use big data analytics to realize personalization. Blended e-learning, on the other hand, has inherited the advantages of both online and live learning has thrived $(\mathrm{Wu}$, Tennyson, \& Hsia, 2010). E-learning has been moving into new directions. In higher education, universities have poured funds into e-learning as they have seen how much the pioneering schools have achieved. In general education, low investment cost attracts more and more schools to e-learning and blended education, which has benefitted the students. In the domain of enterprise training, e-learning is likely to expand as small and medium enterprises become aware of its power. MOOCs growing up as a shared economic model has brought in a ground-breaking change that has affected every corner of education, benefiting learners while posing challenges to the traditional education system (Brugha \& Restoule, 2016; García-Peñalvo, Fidalgo-Blanco, \& Sein-Echaluce, 2018; Ha, Le, \& Trung-Kien, 2019; M. H. Nguyen, Tran, \& Huynh, 2019).

\section{Conclusion}

Over time, universities have changed from being teacher-centric to being learner-centric. With the development of the Internet and the support of multimedia technology, students can learn anytime and anywhere with e-learning and interact well in the classroom visually through the integration of text, images, sounds, and video. This article briefly introduces the history of formation and e-learning development from the perspectives of technology, education, and economy. It provides us with a complete systematic and informative view of e-learning for easy access to a given 
training orientation and being popular in the world and also in Vietnam in recent years.

\section{Acknowledgements}

The authors gratefully acknowledge the National Technology And Science Program on Education Science, Vietnam Ministry of Education and Training (MOET) for funding this research. The authors also acknowledge Ho Chi Minh City Open University, Vietnam, for helping this research.

\section{References}

Alfita, L., Kadiyono, A. L., Nguyen, P. T., Firdaus, W., \& Wekke, I. S. (2019). Educating the external conditions in the educational and cultural environment. International Journal of Higher Education, 8(8), 34-38. https://doi.org/10.5430/ijhe.v8n8p34

Asih, E. S., Kasmi, Nguyen, P. T., Lydia, E. L., Shankar, K., Hashim, W., \& Maseleno, A. (2019). Mobile E-commerce website for technology-based buying selling services. International Journal of Engineering and Advanced Technology, 8(6), 884-888. https://doi.org/10.35940/ijeat.F1167.0886S19

Ayshwarya, B., Nguyen, P. T., Alismi, Abadi, S., Shankar, K., Hashim, W., . . Maseleno, A. (2019). Design analysis of web-based furniture marketing information system. International Journal of Recent Technology and Engineering, 8(2 Special Issue 3), 1513-1519. https://doi.org/10.35940/ijrte.B1277.0782S319

Ayshwarya, B., Yansyah, A., Nguyen, P. T., Shankar, K., Hashim, W., Abadi, S., . . Maseleno, A. (2019). Design analysis of web-based employee information system in office of technical implementation unit of education department. International Journal of Recent Technology and Engineering, 8(2 Special Issue 3), 1507-1512. https://doi.org/10.35940/ijrte.B1276.0782S319

Bahrami, N., Liu, S., Ponkratov, V. V., Nguyen, P. T., Maseleno, A., \& Berti, S. (2019). Novel load management for renewable generation sources/battery system through cut energy expenditure and generate revenue. International Journal of Ambient Energy. https://doi.org/10.1080/01430750.2019.1636868

Bari, M., Djouab, R., \& Hoa, C. P. (2018). Elearning current situation and emerging challenges. PEOPLE: International Journal of Social Sciences, 4(2).

Brugha, M., \& Restoule, J. P. (2016). Examining the learning networks of a MOOC. Data Mining and Learning Analytics: Applications in Educational Research, 121.

Castaño Muñoz, J., Redecker, C., Vuorikari, R., \& Punie, Y. (2013). Open Education 2030: planning the future of adult learning in Europe. Open Learning: The Journal of Open, Distance and e-Learning, 28(3), 171-186.

Dhahad, H. A., Hussen, H. M., Nguyen, P. T., Ghaebi, H., \& Ashraf, M. A. (2020). Thermodynamic and thermoeconomic analysis of innovative integration of Kalina and absorption refrigeration cycles for simultaneously cooling and power generation. Energy Conversion and Management, 203. https://doi.org/10.1016/j.enconman.2019.112241

Diem, P. T., \& Ha, N. M. (2013). Analysing the Employment Status of Graduate Students: The Case of Kent International College in Vietnam. Advances in Management and Applied Economics, 3(4), 235.

García-Peñalvo, F. J., Fidalgo-Blanco, Á., \& Sein-Echaluce, M. L. (2018). An adaptive hybrid MOOC model: Disrupting the MOOC concept in higher education. Telematics and Informatics, 35(4), 1018-1030.

Group, B. S. R. (2017). Higher education reports: Online and distance education. Retrieved May, 11, 2018.

Ha, N. M. (2013). The effect of firm's growth on firm survival in Vietnam. International Business Research, 6(5), 142.

Ha, N. M. (2016). The effect of growth on firm survival in vietnam.

Ha, N. M. (2017). Impact of capital structure and cash holdings on firm value: case of firms listed on the Ho Chi Minh Stock Exchange. International Journal of Economics and Financial Issues, 7(1), 24-30.

Ha, N. M., \& An, N. T. (2015). Impact of Work-Family Conflict on Job Performance of Nurses Working for Hopitals In Ho Chi Minh City. Journal of Science Ho Chi Minh City Open University, (4), 16.

Ha, N. M., \& Lam, N. H. (2017). The effects of celebrity endorsement on customer's attitude toward brand and purchase intention. International Journal of Economics and Finance, 9(1), 64-77.

Ha, N. M., Le, N. D., \& Trung-Kien, P. (2019). The impact of urbanization on income inequality: A study in Vietnam. Journal of Risk and Financial Management, 12(3), 146. 
Ha, N. M., \& Luan, N. V. (2018). The Effect Of Employers'attraction And Social Media On Job Application Attention Of Senior Students At Pharmaceutical Universities In Vietnam. International Journal of Business and Society, 19(2).

Ha, N. M., \& Nguyen, T. V. H. (2014). The influence of leadership behaviors on employee performance in the context of software companies in Vietnam. Advances in Management and Applied Economics, 4(3), 157.

Ha, N. M., \& Tam, H. L. (2015). Attitudes and purchase intention towards counterfeiting luxurious fashion products in Vietnam. International Journal of Economics and Finance, 7(11), 207-221.

Harasim, L. (2000). Shift happens: Online education as a new paradigm in learning. The Internet and Higher Education, 3(1-2), 41-61.

Huynh, V. D. B., Nguyen, P. V., Nguyen, Q. L. H. T. T., \& Nguyen, P. T. (2018). Application of Fuzzy Analytical Hierarchy Process based on Geometric Mean Method to Prioritize Social Capital Network Indicators. International Journal of Advanced Computer Science and Applications, 9(12), 182-186.

Hwang, D. J., Yang, H.-K., \& Kim, H. (2010). E-Learning in the Republic of Korea. UNESCO Institute for Information Technologies in Education, Moscow.

JILL, W. (2018). eLearning and Development Trends for 2018. SkillBuilder LMS by BaseCorp Learning System.

Kahiigi Kigozi, E., Ekenberg, L., Hansson, H., Tusubira, F., \& Danielson, M. (2008). Exploring the e-learning state of art. Electronic Journal of E-learning, 6(2), 77-88.

Kasraie, N., \& Kasraie, E. (2010). Economies of eLearning in the 21st Century. Contemporary Issues in Education Research, 3(10), 57-62.

Kentnor, H. E. (2015). Distance education and the evolution of online learning in the United States. Curriculum and Teaching Dialogue, 17(1), 21-34.

Kidd, T. T. (2010). A brief history of eLearning. In Web-based education: Concepts, methodologies, tools and applications (pp. 1-8). IGI Global.

Kustandi, C., Wasan, A., Rusdin, R., Sinlae, A. A. J., Eteruddin, H., \& Nguyen, P. T. (2020). Digital technology for learning mathematics. Journal of Critical Reviews, 7(1), 281-284. https://doi.org/10.31838/jcr.07.01.51

Luong, D.-L., Tran, D.-H., \& Nguyen, P. T. (2018). Optimizing multi-mode time-cost-quality trade-off of construction project using opposition multiple objective difference evolution. International Journal of Construction Management, 01-13.

Lwoga, E. (2014). Critical success factors for adoption of web-based learning management systems in Tanzania. International Journal of Education and Development using ICT, 10(1).

MacKeogh, K., \& Fox, S. (2009). Strategies for embedding e-learning in traditional universities: Drivers and barriers. Electronic Journal of E-learning, 7(2), 147-154.

Maseleno, A., Ayshwary, B., Ivanova, T. N., Hashim, W., Nguyen, P. T., Shankar, K., . . Huda, M. (2019). General theoretical and philosophical aspects of modern education. Revista San Gregorio(32), 211-216.

Moore, J. L., Dickson-Deane, C., \& Galyen, K. (2011). e-Learning, online learning, and distance learning environments: Are they the same?. The Internet and Higher Education, 14(2), 129-135.

Muruganantham, A., Nguyen, P. T., Lydia, E. L., Shankar, K., Hashim, W., \& Maseleno, A. (2019). Big data analytics and intelligence: A perspective for health care. International Journal of Engineering and Advanced Technology, 8(6 Special Issue), 861-864. https://doi.org/10.35940/ijeat.F1162.0886S19

Nguyen, H. M. (2018). The relationship between urbanization and economic growth. International Journal of Social Economics.

Nguyen, H. M., Bui, N. H., \& Vo, D. H. (2019). The Nexus between Economic Integration and Growth: Application to Vietnam. Annals of Financial Economics, 14(03), 1950014.

Nguyen, H. M., Bui, N. H., Vo, D. H., \& McAleer, M. (2019). Energy consumption and economic growth: Evidence from Vietnam. Journal of Reviews on Global Economics, 8, 350-361.

Nguyen, H. M., \& Khoa, B. T. (2019a). The Relationship between the Perceived Mental Benefits, Online Trust, and Personal Information Disclosure in Online Shopping. The Journal of Asian Finance, Economics and Business (JAFEB), 6, 261-270. 
Nguyen, H. M., \& Khoa, B. T. (2019b). A Study on the Chain of Cost Values-Online Trust: Applications in Mobile Commerce in Vietnam. Journal of Applied Economic Sciences, 14(1).

Nguyen, H. M., Nguyen, C., Ngo, T. T., \& Nguyen, L. V. (2019). The effects of job crafting on work engagement and work performance: A study of vietnamese commercial banks. The Journal of Asian Finance, Economics and Business (JAFEB), 6(2), 189-201.

Nguyen, M. (2011). Determinants of Firm Growth in Employment in Vietnam. TMC Academic Journal, 5(2), 34-50.

Nguyen, M. H., \& Khoa, B. T. (2019a). Customer Electronic Loyalty towards Online Business: The role of Online Trust, Perceived Mental Benefits and Hedonic Value. The Journal of Distribution Science, 17, 81-93.

Nguyen, M. H., \& Khoa, B. T. (2019b). Perceived Mental Benefit in Electronic Commerce: Development and Validation. Sustainability, 11(23), 6587.

Nguyen, M. H., Tran, B. T., \& Huynh, L. T. (2019). Relation Between Employees and Customers Affects to the Positive Word of Mouth Through Customer Satisfaction. The Journal of Distribution Science, 17(6), 65-75.

Nguyen, P., \& Nguyen, P. (2020). Risk Management in Engineering and Construction: A Case Study in Design-Build Projects in Vietnam. Engineering, Technology \& Applied Science Research, 10(1), 5237-5241.

Nguyen, Q. L. H. T. T., Nguyen, P. T., \& Huynh, V. D. B. (2019). Roles of e-learning in higher education. Journal of Critical Reviews, 6(4), 7-13. https://doi.org/10.22159/jcr.06.04.02

Noesgaard, S. S., \& Ørngreen, R. (2015). The Effectiveness of E-Learning: An Explorative and Integrative Review of the Definitions, Methodologies and Factors That Promote e-Learning Effectiveness. Electronic Journal of E-learning, 13(4), 278-290.

Persico, D., Manca, S., \& Pozzi, F. (2014). Adapting the technology acceptance model to evaluate the innovative potential of e-learning systems. Computers in Human Behavior, 30, 614-622.

Phong, N. T., Phuc, V. N., \& Quyen, T. T. H. L. N. (2017). Application of Fuzzy Analytic Network Process and TOPSIS Method for Material Supplier Selection. Key Engineering Materials, 728, 411-415.

Phong, N. T., \& Quyen, N. L. H. T. T. (2017). Application fuzzy multi-attribute decision analysis method to prioritize project success criteria. AIP Conference Proceedings, 1903(1), 111-116. https://doi.org/10.1063/1.5011580

Phuc, V. N., Phong, T. N., Vy, D. B. H., \& Quyen, L. H. T. T. N. (2017). Critical factors affecting the happiness: A Vietnamese perspective. International Journal of Economic Research, 14(01), 511-519.

Qodim, H., Herningsih, Nguyen, P. T., Nguyen, Q. L. H. T. T., \& Toding, A. (2019). Educating the information integration using contextual knowledge and ontology merging in advanced levels. International Journal of Higher Education, 8(8), 24-29. https://doi.org/10.5430/ijhe.v8n8p24

Quyen, N. L. H. T. T., Nguyen, P. T., \& Huynh, V. D. B. (2017). Prioritization of social capital indicators using extent analysis method. International Journal of Advanced and Applied Sciences, 4(10), 54-57.

Ramakrishnan, J., Shabbir, M. S., Kassim, N. M., Nguyen, P. T., \& Mavaluru, D. (2020). A comprehensive and systematic review of the network virtualization techniques in the IoT. International Journal of Communication Systems, $n / a(\mathrm{n} / \mathrm{a})$, e4331. https://doi.org/10.1002/dac.4331

Riyanti, K., Sutejo, Ilayaraja, M., Shankar, K., Nguyen, P. T., Hashim, W., \& Maseleno, A. (2019). The weakness examination of wireless network security at the hospital using QoS. International Journal of Engineering and Advanced Technology, 8(6 Special Issue 2), 1045-1050. https://doi.org/10.35940/ijeat.F1317.0886S219

Rodrigues, H., Almeida, F., Figueiredo, V., \& Lopes, S. L. (2019). Tracking e-learning through published papers: A systematic review. Computers \& Education, 136, 87-98.

Starkey, L. (2019). A review of research exploring teacher preparation for the digital age. Cambridge Journal of Education, 1-20.

Supriyono, Ariyanto, D., Singh, N. A., Shankar, K., Nguyen, P. T., \& Rahim, R. (2019). An examination on cloud computing future, privacy of data and possibilities. International Journal of Engineering and Advanced Technology, 8(6 Special Issue 2), 949-953. https://doi.org/10.35940/ijeat.F1288.0886S219

Sutjiatmo, B. P., Erwinsyah, A., Laxmi Lydia, E., Shankar, K., Nguyen, P. T., Hashim, W., \& Maseleno, A. (2019). Empowering internet of things (IoT) through big data. International Journal of Engineering and Advanced Technology, 8(6 Special Issue 2), 938-942. https://doi.org/10.35940/ijeat.F1285.0886S219 
Thanh, V. H., \& Ha, N. M. (2013). The effect of Banking relationship on firm performance in Vietnam. International Journal of Economics and Finance, 5(5), 148-158.

To, A. H., Ha, D. T.-T., Nguyen, H. M., \& Vo, D. H. (2019). The impact of foreign direct investment on environment degradation: Evidence from emerging markets in Asia. International Journal of Environmental Research and Public Health, 16(9), 1636.

Van Nguyen, P., Nguyen, P. T., Thuy, Q. L. H., Nguyen, T., \& Huynh, V. D. B. (2016). Calculating Weights of Social Capital Index Using Analytic Hierarchy Process. International Journal of Economics and Financial Issues, 6(3), 1189-1193.

Vo, D. H., Nguyen, H. M., \& McAleer, M. (2019). CO2 emissions, energy consumption and economic growth: Evidence from the Trans-Pacific Partnership.

Vo, D. H., Van Nguyen, P., Nguyen, H. M., Vo, A. T., \& Nguyen, T. C. (2019). Derivatives market and economic growth nexus: Policy implications for emerging markets. The North American Journal of Economics and Finance, 100866.

Wahyudi, A., Zulela, Marini, A., Choirudin, Ayshwarya, B., Nguyen, P. T., \& Shankar, K. (2019). Government policy in realizing basic education metro. International Journal of Innovative Technology and Exploring Engineering, 8(9 Special Issue 3), 113-116.

Wu, J.-H., Tennyson, R. D., \& Hsia, T.-L. (2010). A study of student satisfaction in a blended e-learning system environment. Computers \& Education, 55(1), 155-164. 